удк 93/94 Станковић Ђ.

930.2

DOI https://doi.org/10.31212/tokovi.2018.3.ant.109-145

Оригинални научни рад

Примљен: 8. 8. 2018.

Прихваћен: 16. 11. 2018.

Michael ANTOLOVIĆ

Faculty of Education

University of Novi Sad mihael.antolovic@pef.uns.ac.rs

Biljana ŠIMUNOVIĆ-BEŠLIN

Faculty of Philosophy University of Novi Sad simunovic@ff.uns.ac.rs

\title{
History as Vallis Aurea. \\ Đorđe Stanković and the Modernization of Serbian Historiography
}

\begin{abstract}
This article addresses the theoretical and methodological conceptions of Đorđe Stanković in the context of the development and modernization of Serbian and Yugoslav historiography in the late $20^{\text {th }}$ and early $21^{\text {st }}$ century. The present study focuses on Stanković's understanding of the epistemological foundations of historical research and its social functions, his new history program and his consistent battle to deconstruct historical stereotypes and affirm the importance of rational, scholarly knowledge.
\end{abstract}

Key words: Đorđe Stanković, Historical Theory, Methodology of Historical Research, Yugoslav Historiography, Serbian Historiography, New History, Social History

In his 1987 exhaustive critical review of Đorđe Stanković's twovolume book Nikola Pašić and the Yugoslav Question, Branko Petranović noted that the chief merit of this work lay in the author's endeavor to apply an interdisciplinary approach to the study of complex issues in contemporary history. Petranović, who was at the time an unparalleled 
authority on the historiography of Yugoslavia, placed Stanković's work "among the very best in the historiography of Yugoslav unification" and judged the author's "call for [...] greater integration of the social sciences" as a deliberate act of scholarly provocation which "leaves him with an even greater obligation in the future". ${ }^{1}$ Petranović's commendations reflected the joy of a devoted scholar who had, for nearly two decades, had the opportunity to observe closely a talented and diligent student of history as he became a historian worthy of his respect, one from whom he could learn, despite the difference in age and experience.

Đorđe Stanković was born in Sloboština, a village in western Slavonia, on $21^{\text {st }}$ January 1944 . He graduated from grammar school in Slavonska Požega. At the time when he began his undergraduate studies in history at the Faculty of Philosophy in Belgrade, this institution of higher education was where the first lectures on the history of the workers' movement and the history of "the people's and later the socialist revolution" were delivered by Jovan Marjanović (1922-1980), "one of the individuals who established the course The History of Yugoslavia" and founded the Department of Yugoslav History. By the early 1960s, Marjanović was enjoying the reputation of a historian whose works had marked a turning-point in the development of Serbian and Yugoslav historiography on the Second World War and on the revolution in Yugoslavia. ${ }^{2}$ Stanković graduated from university in 1966 and received a master's degree in 1969 after defending his thesis titled The Radical Party and the Croatian Question 1921-1923. Encouraged by his advisor and mentor, Jovan Marjanović, he decided to pursue further academic education and focus his studies on the political actions of Nikola Pašić and his role in the process of creating Yugoslavia. He began his university career at the Faculty of Philosophy in Belgrade, as teaching and research assistant to Jovan Marjanović and Branko Petranović. During the 1960s, Stanković had the opportunity to learn from these and other talented, industrious, creative and innovative scholars. During the seventies, he furthered his professional development and research abroad, mainly in France. He defended his doctoral dissertation Nikola Pašić and the Creation of the Yugoslav State 1914-1921 in 1979. Jovan Marjanović passed away only

1 Branko Petranović, „Đorđe Stanković, Nikola Pašić i jugoslovensko pitanje“, Jugoslovenski istorijski časopis 3/1987, 163, 166.

2 Љубодраг Димић, „Марјановић, Јован“, Енциклопедија српске историографије, прир. Сима Ћирковић, Раде Михаљчић, (Београд: Knowledge, 1997), 482-483.

3 Cf. Darko Hudelist, Moj beogradski dnevnik. Susreti i razgovori s Dobricom Ćosićem 2006-2011, (Zagreb: Profil, 2012), 109-119. 
a year later. The position of Head of the Department of Yugoslav History was taken up by Branko Petranović (1927-1994), who had, together with Marjanović, laid the foundations for the study of contemporary history in Serbian and Yugoslav historiography. The year 1979 saw the publication of Petranović's History of Yugoslavia 1918-1978, the first modern synthesis on the history of the Yugoslav state. As both his previous and subsequent works, this book was characterized by "thematic innovativeness, fresh sources, and a novel form". ${ }^{4}$ Around the same time, Đorđe Stanković was made assistant professor. He was promoted to associate professor at the Faculty of Philosophy in Belgrade in 1985. When his good reputation was confirmed by him being appointed full professor in 1990, along with the highest university rank came the obligation to take over from Branko Petranović as Head of the Department of Yugoslav History. ${ }^{5}$ Concurrently, he had to face the collapse and dissolution of a state whose history he had studied for more than a quarter of a century. For the rest of his life, he persistently strived, in accordance with what was expected of him when he began his career as a historian, to "forge new paths" ${ }^{\prime}$ with his works, even in post-Yugoslav Serbian historiography.

Within the academic community of Serbian and Yugoslav (and even post-Yugoslav) historians, Đorđe Stanković enjoyed the reputation of being a leading expert on Nikola Pašić and the creation of the Yugoslav state. During his more than three decades long professional career, Stanković devoted a total of eight books to problems in this area, including scholarly monographs and collections of historical sources. Stanković's first mono-

4 Љубодраг Димић, „Петрановић, Бранко“, Енциклопедија српске историографuje, прир. Сима Ћирковић, Раде Михаљчић, (Београд: Knowledge, 1997), 570572.

5 On Đorđe Stanković see: Р., „Станковић, Ђ. Ђорђе“, Енциклопедија српске историографије, прир. Сима Ћирковић и Раде Михаљчић, (Београд: Knowledge, 1997), 647-648; Михаел Антоловић, „In memoriam - Ђорђе Станковић (1944-2017)“, Споменица Историјског архива Срем 16/2017, 265-267; Миле Бјелајац, „Проф. др Ђорђе Станковић (1944-2017)“, Токови историје 3/2017, 169-172; Мира Радојевић, Љубодраг Димић, „In memoriam - Ђорђе Станковић (1944-2017)“, Политика, 17. август 2017; Милан Терзић, „In memoriam - Ђорђе Станковић 1944-2017“, Војноисторијски гласник 2/2017, 337-339; Drago Roksandić, „Istorijske sudbine. Sjećanje na prof. dr Đorđa Stankovića (Sloboština, 21. 1. 1944. - Beograd, 9. 8. 2017.)“, Prosvjeta 142/2018, 56-57.

6 Petranović, „Đorđe Stanković“, 163, 166. 
graph, titled Nikola Pašić, the Allies and the Creation of Yugoslavia was published in 1984 by Nolit, one of Belgrade's most renowned publishers of historiographical literature at that time, as part of their elite edition The Historical Library. ${ }^{7}$ That meant that his research findings were deemed worthy to be included alongside the works of the most highly-esteemed contemporary historians of the time, including the somewhat older Branko Petranović (1927-1994), ${ }^{8}$ Dragoljub Živojinović (1934-2017), ${ }^{9}$ Čedomir Popov (1936-2012), ${ }^{10}$ and Andrej Mitrović (1937-2013). ${ }^{11}$ It seems significant to mention that between three and four thousand copies of each book were printed in this edition, which was not typical for scholarly literature, and which testified to its positive reception in academic circles across the then Yugoslavia. The following year, 1985, Stankovićs two-volume book on Nikola Pašić and the Yugoslav question was published by the Belgrade Publishing and Graphics Institute (BIGZ). ${ }^{12}$

Stanković wrote his first books on Pašić by building on hitherto mostly unused primary sources, and they are model scholarly monographs. They examine the personality and political actions of the Serbian politician and statesman in the period between the end of the 19th century and the end of the First World War, more precisely until Pašić's death in 1926, and within the broad context of Serbian, Balkan and European politics. Owing to their wealth of facts, a clear methodological structure and fresh interpretations based on Stankovićs excellent knowledge of contemporary Serbian, Yugoslav and the most significant works of global historiography, his monographs on Pašić are among the most valuable

7 Đorđe Stanković, Nikola Pašić, saveznici i stvaranje Jugoslavije, (Beograd: Nolit, 1984) = Никола Пашић, савезници и стварање Југославије, друго проширено издање, (Зајечар: Задужбина „Никола Пашић“, 1995).

8 Branko Petranović, AVNOJ - revolucionarna smena vlasti 1942-1945, (Beograd: Nolit, 1976).

9 Dragoljub Živojinović, Vatikan, Srbija i stvaranje jugoslovenske države 1914-1920, (Beograd: Nolit, 1980). = Драгољуб Живојиновић, Ватикан, Србија и стварање југословенске државе 1914-1920, друго допуњено издање, (Београд: Службени лист СРЈ, 1995).

10 Čedomir Popov, Od Versaja do Dancinga, (Beograd: Nolit, 1976) = Чедомир Попов, Од Версаја до Данцинга, (Београд: Службени лист СРЈ, 1995²) = Чедомир Попов, Од Версаја до Данцинга, (Београд: Завод за издавање уџбеника, 2015).

11 Andrej Mitrović, Prodor na Balkan. Srbija u planovima Austro-Ugarske i Nemačke 1908-1918, (Beograd: Nolit, 1981). = Андреј Митровић, Продор на Балкан. Србија у плановима Аустро-Угарске и Немачке 1908-1918, (Београд, Завод за уџбенике, 2011).

12 Ђорђе Станковић, Никола Пашић и југословенско питање, I-II, (Београд: БИГЗ, 1985). 
works of Serbian historiography in the last decades of the 20th century. Belonging to the same thematic domain are his books Nikola Pašić and the Croats (1995) ${ }^{13}$ and Nikola Pašić, Contributions to His Biography (2006), ${ }^{14}$ which bring together the findings of years of Stanković's research on the different aspects of Nikola Pašić's political activity. He edited a number of first-class historical sources related to Pašić's actions as politician and statesman: from the essay Serbo-Croatian Unity (1995), in which Pašić expressed his views on Serbo-Croatian cooperation, ${ }^{15}$ to many of Pašić's orations, speeches, and reports at the National Assembly of the Kingdom of Serbia during the First World War, and later at the Constituent Assembly and Parliament of the Kingdom of Serbs, Croats and Slovenes (SCS) Nikola Pašić in the National Assembly (vol. 4, 1998), ${ }^{16}$ to the two-volume compilation titled One Hundred Speeches of Nikola Pašić: The Stateman's Art of Rhetoric (vol. 1-2, 2007) ${ }^{17}$ Finally, it was to the history of Serbia in the First World War, to the creation and development of the Yugoslav program by the Serbian government, and to the Yugoslav unification (phenomena and processes which were largely shaped precisely by the state policy of Nikola Pašić) that Stanković dedicated his monograph Serbia and the Creation of Yugoslavia (2009), ${ }^{18}$ which represents a kind of recapitulation of his decades-long research on the Pašić era in the history of Serbia and the Kingdom of SCS.

The second thematic domain to which Đorđe Stanković continually devoted his research efforts was the history of social groups and institutions in the two Yugoslav states, an issue which had, until the 1980s, been almost completely disregarded in Serbian and Yugoslav historiography. He began researching this topic when he was still a postgraduate student. The 50th anniversary of the founding of the Communist Party of Yugoslavia and the League of Communist Youth of Yugoslavia was commemorated at the University of Belgrade with numerous befitting edi-

13 Ђорђе Станковић, Никола Пашић и Хрвати (1918-1923), (Београд: БИГЗ, 1995).

14 Ђорђе Станковић, Никола Пашић. Прилози за биографију, (Београд: Плато, 2006).

15 Никола Пашић, Слога Србо-Хрвата, приредио Ђорђе Станковић, (Београд: Време књиге, 1995).

16 Никола Пашић у Народној скупштини, књ. IV, приредио Ђорђе Станковић, (Београд: Службени лист СРJ, 1998).

17 Сто говора Николе Пашића: вештина говорништва државника, приредио Ђорђе Станковић, I-II, (Београд: Рад, 2007).

18 Đorđe Stanković, Srbija i stvaranje Jugoslavije, (Beograd: Službeni glasnik, 2009). Друго проширено издање: Ђорђе Станковић, Србија 1914-1918. Ратни циљеви, (Нови Сад: Прометеј, Београд: РТС, 2014). 
tions. Jovan Marjanović edited a collection of papers on the student and youth revolutionary movement at the University of Belgrade. ${ }^{19} \mathrm{His}$ associate, the young magister Đorđe Stanković, put together an album of more than 200 pages of original photographs depicting people and events, documents, posters, fliers and other illustrative material about the actions of the Communists and their revolutionary youth organization (skojevci) at the University of Belgrade during the $1930 \mathrm{~s}^{20} \mathrm{He}$ was also one of the authors of the 1971 book Students of the University of Belgrade 1838-1941: A Chronology of Political Life. ${ }^{21}$ Stanković clearly concluded, as did the main author of this chronicle, Andrej Mitrović, that students were "an interesting, but complex topic in historiography, which has its own cultural, political, sociological and psychological aspect". ${ }^{22}$ During the 1980 s and together with Momčilo Mitrović, he edited three substantial volumes of historical sources on the political actions of the Communist Party at the University before and after the Second World War: Proceedings and Reports of the University Committee of the Communist Party of Serbia [CPS] 19451948 (1985), ${ }^{23}$ Minutes and Reports of the Executive Committee of the CPS 1948-1952 (1987), ${ }^{24}$ Minutes of the Action Committee of the University of Belgrade Professional Students' Associations 1939-1941 (1988). ${ }^{25}$ He returned to this subject in 2000, when he published a collection of "essays on social history" titled Students and the University 1914-1954. ${ }^{26}$

Finally, throughout his decades-long work on the history of Yugoslavia, Đorđe Stanković dedicated his attention to the history of historiography, as well as to the theoretical and methodological dimensions

19 Драгомир Бонџић, „Настанак историографије о Београдском универзитету 1945-1980“, Историја 20. века 1/2005, 163-164.

20 Đorđe Stanković, Komunistička partiija i Savez komunističke omladine Jugoslavije na Beogradskom univerzitetu 1929-1941. Spomen album fotografija, (Beograd: Univerzitetski odbor za proslavu 50 godina SKJ i SKOJ, 1970).

21 Andrej Mitrović, Milorad Radević, Đorđe Stanković, Đorđe P. Jovanović, Studenti Beogradskog univerziteta (1838-1941): hronologija političkog života, (Beograd: Univerzitetski odbor za proslavu 50 godina SKJ i SKOJ, 1971).

22 Ibid.

23 Momčilo Mitrović, Đorđe Stanković, Zapisi i izveštaji Univerzitetskog komiteta KPS 1945-1948, (Beograd: Centar za marksizam Univerziteta, 1985).

24 Momčilo Mitrović, Đorđe Stanković, Zapisnici i izveštaji IKKPS 1948-1952, (Beograd: Centar za marksizam Univerziteta, 1987).

25 Момчило Митровић, Ђорђе Станковић, Записници Акционог одбора ССУ Београдског универзитета 1939-1941, (Београд: Центар за марксизам Универзитета, 1988).

26 Ђорђе Станковић, Студенти и универзитет 1914-1954. Огледи из друштвене историје, (Београд: Центар за савремену историју југоисточне Европе, 2000). 
of exploring the past, and insisted on the need to continually assess and conceptually modernize historical research. It was to this third thematic domain of his scholarly work that Stanković dedicated numerous studies, articles, essays and other papers which were compiled in separate books: The Trials of Yugoslav Historiography (1988), ${ }^{27}$ The Challenge of New History (vol. 1-2, 1992-1994), ${ }^{28}$ Historical Stereotypes and Scholarly Knowledge (2004), ${ }^{29}$ and Serbia's Uncertain Past: Selected Scholarly Essays (2014). ${ }^{30}$ His views on the development of historiography are also outlined in the first volume of Historiography under Surveillance (vol. 1-2, 1996), ${ }^{31}$ which he wrote in collaboration with his closest younger associate, Ljubodrag Dimić. Despite its unassuming subtitle: Contributions to the History of Historiography, this book stands as the first systematic overview of the development of historical thought from antiquity until the emergence of modern historical research within Serbian historiography.

Stanković's works on the history, theory and methodology of historical research have often been overshadowed by his books on Nikola Pašić and the creation of Yugoslavia, despite their immense importance for the modernization of Serbian historiography. This article attempts to outline the conceptual foundations of Stankovićs views on the role of historical research and historical knowledge in contemporary society, and the key arguments he used to unsparingly and repeatedly criticize the vulgarization and political instrumentalization of historical research, phenomena which could be observed across the entire territory of the former Yugoslavia, even after the collapse of the one-party political system and the creation of new nation-states.

\section{Modernization of Yugoslav Historiography}

The wide range of Đorđe Stankovićs interests and his inventive potential came to the forefront already in his first works on the history of the University of Belgrade, and still more in his monographs on Nikola Pašić. Additionally, these works announced that Stanković was deter-

27 Đorđe Stanković, Iskušenja jugoslovenske istoriografije, (Beograd: Rad, 1988).

28 Ђорђе Станковић, Изазов нове историје, I-II, (Београд: Издавачко-новински центар Војска, 1992-1994).

29 Đorđe Stanković, Istorijski stereotipi i naučno znanje, (Beograd: Plato, 2004).

30 Ђорђе Станковић, Неизвесна прошлост Србије: одабрани научни есеји, (Нови Сад: Прометеј, 2014).

31 Ђорђе Станковић, Љубодраг Димић, Историографија под надзором, I-II, (Београд: Службени лист СРJ, 1996). 
mined to contribute personally to the modernization of the approach to the study of contemporary history and to bringing Yugoslav historiography closer to the mainstream of historical thought in Europe and the world. The conditions for charting new paths in Serbian and Yugoslav historiography were relatively favorable at the time, primarily due to social and political changes in Yugoslavia. The dogmatic constraints which the revolutionary government had imposed on historiography after the Second World War were gradually being relaxed, as part of a more general liberalization of political relations from the beginning of the 1960s. In addition to broadening their research horizons, leading Yugoslav historians simultaneously recognized that there was a need for theoretical and methodological developments in historical research. ${ }^{32}$ Supporting this judgment is a note from Jovan Marjanović, editor in chief of the Yugoslav Historical Journal (YHJ). This periodical was published from 1935 to 1939 as the organ of the Yugoslav Historical Society and resumed in 1962, as the organ of the Association of Historical Societies (later: Societies of Historians) of Yugoslavia. In the first volume of its new series, Marjanović highlighted the significance of "general issues" such as the theoretical and methodological underpinnings of historical research, topics in general history, as well as topics from the more recent history of Yugoslav peoples, all of which were at the time neglected in Yugoslav historiography. ${ }^{33}$ One of the manifestations of the growing attention given to theoretical and methodological issues in historical research during the 1960s was the 1964 discussion about "the problems of historical research in Yugoslavia", organized by the Commission for Ideological Affairs of the Central Committee of the League of Communists of Yugoslavia. ${ }^{34}$ No later than the following year, the YHJ, the central organ of Yugoslav historiography, published an exhaustive analytical study by the Slovenian historian Bogo Grafenauer (1916-1995) on "methodological problems in historical research".35

32 Станковић, Димић, Историографија под надзором, II, 139-289.

33 Jovan Marjanović, „Uvodna reč“, Jugoslovenski istorijski časopis 1/1962, 3-4.

34 „Problemi jugoslovenske istorijske nauke“, Jugoslovenski istorijski časopis 3/1964, 57-94; „Problemi jugoslovenske istorijske nauke (nastavak)“, Jugoslovenski istorijski časopis 4/1964, 93-107; Коста Николић, Прошлост без историје. Полемике у југословенској историографији 1961-1991, (Београд: ИСИ, 2003), 26-29.

35 Bogo Grafenauer, „Problemi metodologije istorijskih nauka u svetlu nekoliko novih radova o metodologiji istorije“" Jugoslovenski istorijski časopis 1/1965, 41-68. Cf. Bogo Grafenauer, Struktura in tehnika zgodovinske vede: uvod vštudij zgodovine, (Ljubljana: Univerzitetna založba, 1960). 
Efforts were sustained throughout the 1970s to overcome the traditionalist conceptual foundations of Yugoslav historiography (which had, except for the partial adoption of Marxist vocabulary, remained largely unchanged since the beginning of the $20^{\text {th }}$ century) and to modernize historical research, thematically, theoretically, and methodologically. ${ }^{36}$ Virtually at the same time, certain historians in university centers across Yugoslavia were stressing the importance of theoretical and methodological self-reflection which was, with good reason, considered to be a necessary prerequisite for the further development of historical research. They included Bogo Grafenauer in Ljubljana, Mirjana Gros in Zagreb, Milorad Ekmečić in Sarajevo, Čedomir Popov in Novi Sad, and Radovan Samadžić, Sima Ćirković, Andrej Mitrović, and Branko Petranović in Belgrade. ${ }^{37}$ Likewise testifying to the modernization efforts were a number of gatherings, roundtables convened by Radio Belgrade 3, where leading Yugoslav historians discussed the theoretical underpinnings of historical research and its methodology. Deliberating on the limitations and possible courses of development of Yugoslav historiography, they maintained that it was necessary to advance the methodology of historical research and open historiography up to the concepts and findings of other social sciences. Whilst they did not reject the Marxist perspective on society nor its philosophy of history, the leading investigators of history in the then Yugoslavia still pointed to the unscholarly nature of the vulgar-Marxist interpretations of historical events, phenomena and processes. ${ }^{38}$ In 1977, the Historical Society (Society of Historians) of Serbia also organized a gathering under the name The Issue of Theory and Methods in the Study of History. ${ }^{39}$ The modernizing efforts of Yugoslav historians coincided with similar endeavors in other Eastern European socialist countries, which sought to abandon

36 In addition to the aforementioned two-volume work by Đorđe Stanković and Ljubodrag Dimić, a good insight into several aspects of the development of Yugoslav historiography is given in: Snježana Koren, Politika povijesti u Jugoslaviji (19451960). Komunistička partija Jugoslavije, nastava povijesti, historiografija, (Zagreb: Srednja Europa, 2012); Magdalena Najbar-Agičić, U skladu sa marksizmom ili činjenicama? Hrvatska historiografija 1945-1960, (Zagreb: Ibis grafika, 2013).

37 Михаел Антоловић, „О занату историчара: теоријско-методолошка схватања Чедомира Попова“, Споменица академику Чедомиру Попову, (Нови Сад: Матица српска, 2017), 14.

38 Treći Program journal published announcements and discussions from a total of five thematic gatherings dedicated to theoretical and methodological aspects of historical research: Историографија и њени методи (1970), Историја и друге науке (1971), Функција историјске свести (1972), Историја и савремено друштво (1977), Савременост као предмет историје (1980).

39 Историјски гласник 1-2/1978, 7-91. 
the traditionalist paradigm and acknowledge the mainstream of global historiography, while at the same time maintaining the Marxist conception of history. ${ }^{40}$

Growing self-reflection in Yugoslav historical research and its ever-increasing emancipation from the vulgar-Marxist interpretations at the turn of the decade of the 1960s coincided with the period when Stankovic mastered the historian's craft. Having expressed an interest in theoretical and methodological issues in historical research while still in postgraduate education, Stanković continually and closely followed literature from a wide array of social sciences. Even so, it seems that his views on theoretical and methodological issues were immensely influenced by his research stays in France in the mid-1970s ${ }^{41}$ As he was gathering the material for his doctoral dissertation, he familiarized himself with the main currents of contemporary historical thought in France and Europe. Eloquently testifying to Stankovićs interests at the time are the titles of some of the books he reviewed on the pages of the Historical Gazette, a journal which was then published by the Serbian Historical Society (Society of Historians). In addition to the books History and Truth by Marxist philosopher Adam Schaff, History and Truth by one of the leading structuralist philosophers Paul Ricoeur, as well as the works of two distinguished British historians, Geoffrey Barraclough (An Introduction to Contemporary History) and Sidney Pollard (The Idea of Progress), ${ }^{42}$ Stanković reviewed Maurice Bouvier-Ajam's Essays in Historical Methodology, expert in the history of the ancient Rome Paul Vayne's Writing History, the study Historical Materialism and the History of Civilizations by French Marxist theoreticians Antoine Pelletier and Jean-Jacques Goblot, The Nature of History by the prominent strategist and military writer André Beaufre, and Léon-E. Halkin's handbook titled Elements of Historical Criticism. ${ }^{43}$ The

40 Cf. Georg G. Igers, Istorijska nauka u 20. veku. Kritički pregled u međunarodnom kontekstu, (Beograd: Arhipelag, 2014), 70-71; Georg G. Iggers, Ein anderer historischer Blick. Beispiele ostdeutscher Sozialgeschichte, (Frankfurt am Main: Fischer-Taschenbuch-Verlag, 1991).

41 Darko Hudelist, Moj beogradski dnevnik, 116. Cf. Stanković, Iskušenja jugoslovenske istoriografije, 293.

42 Ђорђе Станковић, „Adam Schaff, Histoire et Vérité. Essai sur l'Objectivité de la Connaissance Historique, Paris 1971; Paul Ricoeur, Histoire et Vérité, Paris s. a.; Geoffrey Barraclough, An Introduction to Contemporary History, London 1970; Sidney Pollard, The Idea of Progress. History and Society, London 1971“, Историјски гласник 1-2/1974, 173-178.

43 Ђорђе Станковић, „Maurice Bouvier-Ajam, Essai de méthodologie historique, Paris 1970; Joseph Hours, Valeur de l'histoire, Paris 1971; Paul Veyne, Comment on écrit 
above-mentioned reviews bear witness to the breadth of Stanković's professional interests, which in many ways exceeded the mainstream of Yugoslav historiography, but also to the intellectual influences he followed whilst constructing his own conception of historical research.

During the 1970s, Stanković familiarized himself with the leading schools of thought that had defined historical thinking in post-World War II Europe. Particularly important was the fact that he had first-hand insight into the development of the French Annales School, which was, at the time, already recognized as a desirable route for modernizing historical research by notable Yugoslav historians such as Čedomir Popov and Mirjana Gros. ${ }^{44}$ However, encouragement for the critical evaluation of the historiographical heritage and for theoretical and methodological innovations in Yugoslavia in the 1980s, came only from a few historians who were open to an undogmatic Marxist theory of society. ${ }^{45}$ In the historical field (defined by Pierre Bourdieu as a hierarchically organized area of society that reflects the real distribution of different types of power, namely, economic, social, cultural and symbolic capital), ${ }^{46}$ research on contemporary history was, even during the period of late socialism, marked by a strong influence of the ruling ideology.

During that time, there also existed a strong dogmatic current in Yugoslav historiography. On the one hand, it refused to critically reevaluate phenomena such as World War II and the socialist revolution in Yugoslavia and, on the other, it was not prepared to relinquish its utterly traditionalist conception of history, the tenets of which were positivism

l'histoire, Paris 1971; Antoine Pelletier, Jean-Jacques Goblot, Matérialisme historique et histoire des civilizations, Paris 1973; André Beaufre, La nature de l'histoire, Paris 1974; Léon-E. Halkin, Éléments de critique historique, Liège 1974“, Историјски гласник 1-2/1976, 183-187.

44 Антоловић, „О занату историчара“, 17; Branimir Janković, Mijenjanje sebe same. Preobrazbe hrvatske historiografije kasnog socijalizma, (Zagreb: Srednja Europa, 2016), 69-72, 81-91.

45 For more information, see the thematic issues of the Marksizam u svetu journal: "Pitanja marksističke istoriografije" (1983), "Marksističko shvatanje istorije" (1984), as well the thematic issues of the Марксистичка мисао journal: "Савременост и историјска свест" (1985) and “Револуција и историографија" (1986). The proceedings from the "week of Marxist debates" held in Neum in early 1985 are also informative: Istoriografija, marksizam i obrazovanje, (Beograd: Izdavački centar Komunist, 1986).

46 The concept of historical field as an analytic category was introduced into Croatian historiography by Branimir Janković, following Pierre Bourdieu, to describe the dynamics of power within historiography and its role in society. Janković, Mijenjanje sebe same, 12-13. 
and the selective implementation of certain elements of Marxist social theory. Theoretical and methodological aspects of historical research received modest attention during the aforesaid decade. Most of the debates at the time were ideologically motivated and they reflected the political and national tensions within the Yugoslav state. ${ }^{47}$ The already sparse discussions about methodological issues were mostly dedicated to criticizing those methodological approaches to the study of the past that deviated from the prescribed canon of Marxist historical thought. This applied, among others, to the French Annales School and its relatively few advocates in Yugoslavia. ${ }^{48}$

At the time, Branko Petranović played a key role in modernizing historical research and opposing dogmatic interpretations in the field of contemporary history ${ }^{49} \mathrm{He}$ dedicated numerous works to theoretical and methodological issues in historical research, which found itself under the surveillance of the "revolutionary subject" in the one-party system of socialist Yugoslavia. Beginning by critically evaluating a wide array of historical sources and continually assessing and questioning historical methodology, to expanding the thematic scope of historical research, he repeatedly insisted on the importance of obtaining objective historical knowledge. ${ }^{50}$ Unlike most historians who directed their attention to the political and party dimensions of contemporary history and interpreted it from shopworn ideological perspectives, Petranović advocated a broad conception of historical research which would, in addition to political and military events, have to encompass the demographic structure, social processes, economic relations, cultural developments, but also a distinctive value system (tradition), and religious and ideological beliefs. He thus came closer, in many ways, to the ideal of total history, as espoused by the French Annales School. ${ }^{51}$

47 Mirjana Gross, „Historija: ideologija i (ili) znanost“, Istoriografija, marksizam i obrazovanje, (Beograd: Izdavački centar Komunist, 1986, 163-179); Николић, Прошлост без историје, passim.

48 See Historija i suvremenost. Idejne kontroverze, (Zagreb: Centar CKSKH za idejno-teorijski rad „Vladimir Bakarić“, Delo, Globus, 1984), as well as the collection of papers: Metodologija savremene istorije (Saopštenja sa Okruglog stola održanog 17. i 18. decembra 1985. godine u Beogradu), (Beograd: ISI, 1987).

49 Димић, „Петрановић, Бранко“, 570-572.

50 Branko Petranović, Istoriografija i revolucija, (Beograd: Prosveta, 1984).

51 Petranović's criticism of the traditionalist approach marked by outdated methodology, the presence of ideological evaluations taken over from the language of politics, and the depersonalisation of historical reality, among other things, was succintly expressed in his review of Venceslav Glišić's book dedicated to the Republic of Užice: 


\section{Social History as a Form of Total History}

Since he agreed with Petranovićs view that total history was the ideal goal of historical research, Đorđe Petranović emphasized that the condition for achieving that goal was to open historical research up to the methods and findings of other social sciences and humanities. This was in accordance with similar methodological revolutions which occurred some two decades earlier in great western historiographies, and which were characterized by widening the scope of historical research to include all social phenomena and processes. This paradigm shift in cultures with developed historiographies was marked by a suppression of traditional political history and the rise of different forms of a broadly conceived social history (history of society), whilst narration, the dominant means of presenting historical knowledge, was being replaced by a problem-oriented historical analysis. ${ }^{52}$

Stanković published his first theoretical and methodological works already at the beginning of the $1980 \mathrm{~s} \cdot{ }^{53}$ It was the history of the University of Belgrade (in which he himself had participated) that he placed under methodological scrutiny and scholarly criticism, noticing that "in the bulk of historical literature published until that time, opinions on the history of the student movement were dictated by the attitudes of the ruling party, which had, in that way, evaluated its past; they were descriptive, narrowed down to political, organizational and personal dimensions, and in many ways one-sided, dogmatic, and ideologically charged." Around the same time, Stanković also formulated innovative proposals for "moving past the traditional approach and applying new methods" in the study of contemporary history. These proposals included, among other things: es-

Branko Petranović, „Venceslav Glišić, Užička republika“, Jugoslovenski istorijski časopis 1-2/1987, 187-199.

52 Eric Hobsbawm, „From Social History to the History of Society“, Daedalus 1 (1971), 20-45. = Erik Hobsbaum, $O$ istoriji. $O$ teoriji, praksi i razvoju istorije i njenoj relevantnosti za savremeni svet, preveo sa engleskog Mašan Bogdanovski, (Beograd: Otkrovenje, 2003), 84-106; François Furet, „De l'histoire-récit à l'histoire-problème“, Diogène: revue internationale des sciences humaines 89/1975, 116-131. = Франсоа Фире, Радионица историје, превела с француског Јелена Новаковић, (Сремски Карловци, Нови Сад: ИКЗС, 1994), 94-116.

53 Ђорђе Станковић, „Нове могућности проучавања револуционарног субјекта“, Марксистичка мисао 6/1981, 186-206; Ђорђе Станковић, „Социјална историја и личност“, Марксистичка мисао 4/1983, 33-44; Ђорђе Станковић, „Београдски универзитет - политичке и историографске контроверзе“, Марксистичка миcao 5/1983, 165-180. 
tablishing theoretical grounds for undertaking research, adopting an interdisciplinary approach and contextualizing the subject matter, gathering, analyzing and critically evaluating primary and secondary historical sources, applying quantitative and qualitative analyses to the collected data, and constructing a rational historical narrative. According to Stanković, the historian's craft required the application of comprehensive knowledge and diverse skills in creating (writing) a social, i.e. total history. ${ }^{54}$

After two books dedicated to Nikola Pašić, which could also be understood as an attempt at a scholarly reply to the mystification of characters and phenomena of the recent past (a very common occurrence in Yugoslav society during the 1980s), ${ }^{55}$ Stanković published a collection of historical essays, reviews and studies titled The Trials of Yugoslav Historiography. This book, which can be described as a kind of manifesto of new history, contained his previously-published theoretical and methodological works, as well as the findings of concrete research efforts carried out in accordance with the principles of new, social, total history. Drawing on his excellent understanding of the main currents of contemporary historical thought, Stanković analyzed the theoretical and methodological framework of Yugoslav historiography, as well as its role in contemporary Yugoslav society - a society burdened by the terror of history, i.e. by different forms of deeply ingrained concepts about the past. Similarly to Andrej Mitrović, who at the time claimed that an emotional attitude towards the past politicized one's historical consciousness and prevented one from acquiring objective historical knowledge, ${ }^{56}$ Stanković's starting position was that, in times of a general crisis of the Yugoslav state, "historical research was itself affected by the crisis and parochial divisions, incapable of adequately examining, recognizing and uncovering the pitfalls of this terror of history, and therefore unable to help Yugoslav society see itself in the world history of the $21^{\text {st }}$ century". ${ }^{57}$ Stanković found the cause of this state of affairs in the conceptual underdevelopment of Yugoslav historiography, judging that historical research in Yugoslavia was based on three outdated "dominating theoretical and methodological models". Predominating on the one side was "traditionalist political historiography", while on the other there was dogmatic Marxist historiography, and

54 Dragomir Bondžić, „Razvoj istoriografije o Beogradskom univerzitetu 1980-2004“, Istorija 20. veka 1/2006, 133-134.

55 Cf. Николић, Прошлост без историје, passim.

56 Андреј Митровић, „Савременост и историјска свест“, Марксистичка мисао 2/1985, 9.

57 Stanković, Iskušenja jugoslovenske istoriografije, 10. 
between the two extremes lay "Marxist positivism", portrayed as a sort of "middle ground". ${ }^{58}$ Stanković believed that all three models were inadequate, not only from the standpoint of contemporary currents of historical thought, but also because they represented extremely ideologized approaches to the study of history, which ignored the totality of society and reduced the entire past to the history of the class struggle, i.e. the history of the Communist Party. In Stanković's mind, Yugoslav historiography of contemporary history was characterized by the "terror of factography" from the domain of political life, that is, by "high levels of party bias within academia", and it offered an incomplete and oftentimes distorted image of the past. Such a historiography contributed to the strengthening of "nationalist myths and an irrational historical consciousness". ${ }^{99}$ This was unacceptable to Đorđe Stanković, even though he was aware that historical research had very little impact on forming the historical consciousness of the largest social classes. As he himself pointed out, they were primarily influenced by family, religious organizations, journalistic and feuilleton-like texts, historical novels, comic books, but also by the defeated side of the Yugoslav revolution ("the remains of the bourgeoisie") and the dissidents among the Yugoslav communists ("the disruptive elements in the revolutionary subject"). ${ }^{60}$ For that reason, he openly spoke as an advocate of a conceptual (theoretical and methodological) modernization of Yugoslav historiography. He believed that innovative approaches to studying the past allowed historiography to stimulate the emancipation of society from inherited historical stereotypes, misconceptions and half-truths. ${ }^{61}$

Ideas about the need to theoretically and methodologically improve historical research were, by the mid-1980s, accepted by the most distinguished historians of the then Yugoslavia. Nevertheless, unlike the significant number of Yugoslav historians who nominally identified themselves as Marxists, even though they simultaneously applied a traditionalist methodology, Stanković recognized the wide range of possibilities given to social history by the Marxist theory of society. Building on this theory with elements of the critical theory of society and existentialist philosophy, as well as different forms of social history, Stanković identified social history as a desirable theoretical concept, considering that it would "be capable of exploring and explaining all the richness of human

58 Ibid., 52-53, 99-103.

59 Ibid., 101, 118-119, 240.

60 Ibid., 70-82.

61 Ibid., 108. 
life in the past". Maintaining that political historiography narrowly conceived was obsolete from the standpoint of modern historical though and that it could not meet the requirements of neither modern historiography nor modern society, Stanković pushed for a reconsideration of inherited theoretical and methodological assumptions and their reinvention in the form of pronounced interdisciplinarity and the adoption of methods and findings from other social sciences. Seeing their "findings about man, personality and society as too provocative to be disregarded by historians," he emphasized that an imperative for social history was to "constantly enrich historical research with insights from philosophy (especially social anthropology) and psychology (especially social psychology and personality psychology)," so that it could provide as comprehensive scholarly answers as possible to current issues. Primarily having in mind the need for opening up academic historiography to the social sciences, he emphasized that it was essential "only to apply more radically the findings of the other social sciences, intensify the study of neglected issues, formulate certain topics more freely, and gradually do away with individual and collective methodological narrow-mindedness and dogmatism." ${ }^{\prime 2}$ Stanković believed that traditionalist political history, which dominated in academic circles in Yugoslavia in the late 1980s, facilitated all sorts of misuses of historical knowledge, and he was convinced that a theoretical and methodological transformation of historiography into a social history could make it vastly more objective and analytical. This transformation, he emphasized, would "free historiography and our collective consciousness from distorted perceptions of the past." In other words, Đorđe Stanković believed that the mission of new history was to "eliminate the one-sidedness of traditional history and restore the study of man's past into a completely social context." ${ }^{\prime 63}$

This new history program required that historians and historiography be socially involved. For Đorđe Stanković, social history was principally an adequate scholarly means of combating historical myths and the political instrumentalization of insights about the past; however, the proposed program also had certain revolutionary characteristics, since it questioned the conceptual basis of the best part of Yugoslav historiography at the time. This is particularly significant if one has in mind that Stanković's proposal to extend the domain of historical research to all social events, phenomena and processes (instead of exclusively studying no-

62 Ibid., 11-12, 22, 24.

63 Ibid., 26, 69, 240. 
table political figures, largely outside the social context in which they lived and worked), essentially called for the development of a special methodology that would include everything from identifying and analyzing new types of historical sources, to determining historical facts, to constructing new models of interpretation. New history also demanded that historians master the theoretical knowledge and terminology of a number of different social sciences.

Although he was not entirely alone in his promotion of interdisciplinarity in historical research and his push for the development of social history, Stanković's ideas were among the most coherent and most comprehensive. Already at the beginning of the 1980s and with the help of a younger colleague, Drago Roksandić, who was at the time a teaching assistant in the Department of History at the Faculty of Philosophy in Belgrade, he tried to implement the principles of new history in their critical review for the sixth (and final) volume of the History of the Serbian People, published in 1983. A number of leading historians had collaborated on the work, yet to Stanković and Roksandić it represented the peak of traditional historiography and indicated that traditional historiography had "despite significant innovations, fulfilled its historical duty and, at the same time, raised a number of questions about its own development, based on postulates with varying degrees of similarity." ${ }^{16}$ Roksandić argued that the concept of social history as an alternative to traditional history "lacked unanimous support, so that even its most arduous followers caution about the many open questions related to it." ${ }^{65}$ Precisely some of the most distinguished historians who supported the modernization of historical research, such as Branko Petranović and Čedomir Popov, expressed certain reservations about "uncritical interdisciplinarity," arguing that it was necessary for historical research to preserve its methodological and subject-matter identity against the other social sciences. ${ }^{66} \mathrm{How}-$ ever, even though he brought up "major taboo topics," Stanković was able to establish a close and cordial collaboration with leading Yugoslav historians of the older generation, as well as with his younger colleagues. ${ }^{67}$

$64 \quad$ Ibid., 137-138.

65 Драго Роксандић, „Глобална историја и историјска свест“, Марксистичка мисао 4/1983, 50.

66 Антоловић, „О занату историчара“, 25-26; Petranović, Istoriografija i revolucija, 15-43, 125-126; Бранко Петрановић, Историографске контроверзе, (Београд: Службени лист СРJ, 1998), 37-38. Cf. Janković, Mijenjanje sebe same, 164.

67 Бјелајац, „Проф. др Ђорђе Станковић (1944-2017)“, Токови историје 3/2017, 170. Сf. Станковић, Изазов нове историје, I, 16. 
Like Branko Petranović, Andrej Mitrović, and Čedomir Popov, Stanković came forward in the mid-1980s as a persistent critic of ideological ("class-based") and nationalistic ("patriotic") historical interpretations, and stressed that the goal of historical research was to provide rational insights about the past, which would serve as a foundation for the formation of a society's historical consciousness. ${ }^{68} \mathrm{He}$ pointed out that "myths and legends, just like the manipulation of the past for political and ideological ends, only amplify the trauma of a people." He criticized historians who were "stylizing a new, almost pastoral nostalgia for the good old times", thereby aggravating the crisis of the Yugoslav society with their nationalistic interpretations. ${ }^{69}$ Advocating, like Mirjana Gros and her collaborators, to abandon the concept of "traditionalist political historiography", Stanković argued that there was a need to "educate the academic staff who will study the social history of individual Yugoslav peoples in its integrity."70 $\mathrm{He}$ also emphasized the need to cultivate dialogue ("cultivate scholarly disputes") and "pursue scholarly criticism" within the community of Yugoslav historians as the only sound way of finding scholarly answers to controversial questions from Yugoslav history. ${ }^{71}$

\section{New History as a Historiographical Response to a Social Crisis}

The collapse of the socialist system, the emergence of political pluralism and the dissolution of the Yugoslav state in the early 1990s showed the full complexity of the relationship between "the historian and the modern era," given that the aforementioned processes were followed by "uses and abuses of history" from the standpoint of restored and mu-

68 Cf. Бранко Петрановић, „Дезинтеграција историјске свести о револуцији“, Марксистичка мисао 4/1983, 59-82; Андреј Митровић, „Седам теза о месту и улози историјске науке у историјској свести“, Марксистичка мисао 4/1983, 3-19; Чедомир Попов, „Револуција и историографија. Расправе“, Марксистичка мисао 6/1986, 189-192.

69 Stanković, Iskušenja jugoslovenske istoriografije, 120, 142.

70 Ibid., 89-90. Cf. Janković, Mijenjanje sebe same, 91-97.

71 Stanković, Iskušenja jugoslovenske istoriografije, 117, 123. Сf. Драго Роксандић, „Савременост и историјска свест“, Марксистичка мисао 2/1985, 85; Миомир Дашић, Спорења у историографији. О врлинама и манама „Учитељище живота“, (Подгорица: ИТП Унирекс, Бијело Поље: ИГП ПЕГАЗ, 2014), 475-480; Metodologija savremene istorije (Saopštenja sa Okruglog stola održanog 17. i 18. decembra 1985. godine u Beogradu), 221-256. 
tually opposed nationalist ideologies. ${ }^{72}$ Stanković's views on historical research and its role in a period of total crisis caused by the civil war in former Yugoslavia and the international isolation of the Federal Republic of Yugoslavia, were presented in numerous scholarly essays, academic papers and interviews, which were subsequently compiled between the covers of his Challenges of New History (vol. 1-2, 1992-1994) and Historical Stereotypes and Scholarly Knowledge (2004).

Building on his understanding of social history from the mid1980s, in the 1990s Stanković expressed a particular interest in new theories of society and the elite, the relationship between the elites and the masses, different types of authority (particularly Weber's concept of charismatic authority), as well as the possibility to apply psychoanalysis in interpreting history. Following the postulates of one of the founders of psychohistory, Erik Erikson, he suggested that analyzing historical figures "through the prism of modern and verified methods of psychobiography [...] is certainly one of the primary tasks of contemporary historical research." ${ }^{\prime 3}$ Nonetheless, it seems that what chiefly shaped his theoretical and methodological views were the stimulating concepts of French new history, which, in addition to studying social structures, anthropology and mentality, assigned a hugely important role to the history of private life and gender history. Following global currents of historical thought, Stanković pointed to the unjustified neglect of the gender aspect of history, since "the life of women, children and the youth has become a focus of interest only in the last few decades." ${ }^{74}$

He remained consistent in defending the attitude that the creation of the Yugoslav state had been a progressive historical act for all Yugoslav peoples. This view went completely counter to the main currents of the new historical discourse, which was united in rejecting "the Yugoslav experience of Serbian national integration" (Branko Petranović). Stanković persistently confronted the rising tide of nationalism in public life, as well as the nationalistic (re)interpretations of the past. He emphasized that certain historians had, by reviving irrational and mythomaniacal interpretations of the past, greatly contributed to the "destruction of the historical mind" (Andrej Mitrović), ${ }^{75}$ i.e. to the political instrumentalization of his-

72 Бранко Петрановић, Историчар и савремена епоха, (Београд: Новинско-издавачка установа „Војска“, 1994), 63-64.

73 Станковић, Изазов нове историје, I, 177.

74 Станковић, Изазов нове историје, II, 221, 227.

75 Andrej Mitrović, Raspravljanja sa Klio. O istoriji, istorijskoj svesti i istoriografiji, (Sarajevo: Svjetlost, 1991), 135. 
torical knowledge, thus betraying both the ethics and the methodological principles of their profession. Characteristic in that sense is Stanković's judgment that historical research used for political ends "is undeniably one of the causes of the global crisis, and the crisis in Yugoslav society." ${ }^{16}$

During that period of all-encompassing crisis in Yugoslavia, it was clear that historical research was faced with a crisis as well. Assessing the scale at which historical knowledge was exploited in politics, the media, but also in academic discourse, Stanković claimed that "the past has become the subject of the greatest political manipulation; irrationality is overriding the rational spirit, and mythology is overpowering critical awareness [...]." What is more, he considered that historical research had, since the early 1990s, been in a state of "historiographical shock."77 The above-mentioned circumstances did not, however, shake his conviction that there was a need to theoretically and methodologically develop historical research in the direction of social history. On the contrary, he remained true to his previously stated views to which he added by gaining new insights into the development of social theory. According to him, "integration of history with related [social] sciences is an imperative of the times." He insisted that the most pressing task of historical research was to provide rational historical insights, and employ new history to encourage younger historians to look for new ways of exploring and discovering history, while at the same time "protecting historical research from the invasion of uncritical and irrational conservatism, which is nowadays washing over the entire planet." ${ }^{\prime 8}$

It was during this period of crisis in society and academia that Stanković, together with his younger colleague Ljubodrag Dimić, wrote the book Historiography under Surveillance (1996). In the preface to this two-volume work, Stanković emphasized both authors' awareness that "a completely new period" of Yugoslav historiography is beginning, and expressed the sense of responsibility he felt "toward his students" but also toward the wider reading audience in that period of "historiographical anarchy" and a somewhat "provisional state of scholarship." The authors' aim was to "lay out the viable paths of development in Yugoslav historiography with the highest degree of tolerance, common sense and knowledge" based on a "critical assessment of general and specific historiograph-

76 Станковић, Изазов нове историје, I, 9. Cf. Andrej Mitrović, Vreme destruktivnih. Intervjui, priredio Dragan Štavljanin, (Čačak: Čačanski glas, 1998), 224.

77 Станковић, Изазов нове историје, II, 188, 247, 258.

78 Станковић, Изазов нове историје, I, 10, 16, 202. 
ical insights." ${ }^{\prime 9}$ Reviewing the book were Latinka Perović, who was at the time Head of the Institute for Recent History of Serbia and editor of the journal Currents of History, and Milan Ristović, Professor of Contemporary History at the Faculty of Philosophy in Belgrade and editor of the journal Annual for Social History (which was launched in 1994 at the initiative of Andrej Mitrović). Stanković and Dimić succeeded in "giving an overview of the development of historiography in the past, aware that without doing so, they could not hope to understand the problems of contemporary historiography." They were also successful in presenting "three generations of Yugoslav historians: from Stanoje Stanojević, Viktor Novak, Vasa Čubrilović, and Dragoslav Stranjaković, to Dragoslav Janković and Bogo Grafenauer, and finally to Jovan Marjanović, Bogumil Hrabak and Branko Petranović." According to Latinka Perović, Stanković's overview of the history of historiography "from myth to science" successfully showed that historical research was "one of the most sensitive barometers of a society's spiritual condition." The authors dealt with questions that "deserve attention and are worthy of academic discussions: the proportion of the general and the specific in the history of historiography, Yugoslav historiography in the history of our historiography, the historian." Despite its uniqueness and scholarly value, the work, at least in the view of Latinka Perović, received a "lukewarm response" in the professional community, which was already at that time characterized by "writing more than it was reading." ${ }^{\prime 00}$ Still, this overview of the history of Yugoslav historiography from the mid-1940s until the mid-1960s, placed in the context of the development of "historiography into an academic discipline in general" did not go completely unnoticed. In fact, it was identified as a "turning-point" that testified "to the maturity of a national historiography" and inspired further academic deliberation and discussion. The authors were recognized as being "among the leading Serbian historians of the now middle, and, until recently, younger generation, until Branko Petranović's death; among the leading in terms of historiographical production, interest in research methodology, and ex cathedra influence on upcoming generations of historians." Despite certain critical remarks, Dorđe Stanković and Ljubodrag Dimić were commended for "taking upon their shoulders not only the historiography of the entire world, but also the (self-)awareness

79 Станковић, Димић, Историографија под надзором, I, 18.

80 Latinka Perović, „Dva značajna istoriografska dela: povodom drugog izdanja knjige Branka Petranovića, Istoričar i savremena epoha i dvotomnog dela Đorđa Stankovića i Ljubodraga Dimića, Istoriografija pod nadzorom", Istorija 20. veka 1/1998, 163-164. 
of the responsibility they had for their own surveillance over historiography, and the risk to which they exposed themselves once they cross the threshold of SAFETY! [Emphasis in the original]."

At the beginning of the $21^{\text {st }}$ century, Dorđe Stanković persistently advocated for interdisciplinarity, claiming that "young scholars should, as soon as possible, be trained to 'reexamine historical sources' through a prism of political sociology, sociology of religion, political philosophy, social psychology, etc. - depending on the field of history they are working in." Bearing in mind that historiography was at the time being written in a thoroughly different social context than at the time of its inception, Stanković believed that historical research could not ignore reality, but rather that it had to respond to the demands of modern society. He emphasized that the "need for new history is a need for new and more diverse insights about the past, since man's life is becoming ever more complex, ever richer, and it is that fullness that historians should objectively investigate." The main reason for this was so that, "through social history, the historian could 'capture man's everyday life', and through that manifold practice of living, reach new, more general and global insights." ${ }^{\prime 2}$

Until the end of his professional career, Stanković continued to stress the importance of innovative theoretical and methodological concepts and of including Serbian historiography into European and global historiographical currents. Perhaps the best example that he considered consistency and persistence as his obligation is the fact that he began his Historical Stereotypes and Scholarly Knowledge, published in 2004, with only a slightly modified and revised version of his preface to The Trials of Yugoslav Historiography, which he had written in $1988 .{ }^{83}$ He persistently stressed the need to enhance the professional development of Serbian historians by systematically introducing them to influential trends in contemporary historical thought. In order to gain as complex an insight as possible into all aspects of society in the past (the core subject of historical research), he deemed it necessary that new generations of Serbian historians should master the core concepts of social theory (social structure and mobility, class and status, mentality, sex and gender, ideology). Apart from French new history, to which he had pointed since the mid-

81 Smiljana Đurović, „Nadzor pod nadzorom. Metodološka razmatranja o tome kuda idu kretanja u procesima saznanja“, Tokovi istorije 3-4/1997, 245, 255.

82 Stanković, Istorijski stereotipi i naučno znanje, 267.

83 Cf. Stanković, Iskušenja jugoslovenske istoriografije, 7-17; Stanković, Istorijski stereotipi i naučno znanje, 5-14. 
1970s, new economic history, and different forms of social history, he also emphasized the importance of new historiographical schools and movements, such as the new history of political thought, history from below, microhistory, history of everyday life, gender history and history of reading. ${ }^{84}$

Following Peter Burke in promoting "new perspectives on historical writing," ${ }^{85}$ Stanković also emphasized the importance of mastering new types of historical sources. Besides traditional historical sources, which usually originated in the work of organs of state or state institutions, he warned that, in order to implement the broadly conceived program of new history, it was necessary to expand the heuristic basis of historical research and analyze the different types of oral testimonies (from interviews to the "oral tradition of different generations"), ethnological records, court documents, personal artifacts (private correspondences, diaries, recollections, memory books of "ordinary people"), as well as the press (particularly social chronicles), church books, the archives of health, educational, cultural organizations, etc. In an endeavor to show that everyday experiences of the "little man" could be a legitimate object of historical research, Stanković wrote a methodologically innovative research article about the exodus of the Golden Valley Serbs, based precisely on the abovementioned theoretical and methodological approaches. Exploring the past of his Slavonian homeland in line with the principles of French new history, ${ }^{86}$ Stanković depicted the history of the Serbian people in the settlements of Požega Valley in the form of a complete microhistorical study. This work is one of the first in Serbian historiography to adopt the "new model of everyday history". ${ }^{87}$ Apart from being a kind of plea for the exploration of private and everyday life, the Exodus of the Golden Valley Serbs marks the birthplace of this subdiscipline in Serbian historiography. However, even though he persistently spoke in favor of modernizing historical research, Stanković maintained a sober and critical attitude toward the different currents within contemporary historiography. He argued that new history in its many forms was not negating traditional (political, diplomatic) history, but rather rectifying it by extending the scope of historical research to include different dimensions of man's life in soci-

84 Stanković, Istorijski stereotipi i naučno znanje, 218-222.

85 Cf. Peter Burke, New Perspectives on Historical Writing, (University Park, PA: The Pennsylvania State University Press, 2001).

86 Станковић, Изазов нове историје, II, 221; Stanković, Istorijski stereotipi i naučno znanje, 212-213.

87 Станковић, Изазов нове историје, II, 224. 
ety. He believed that "a spirit of coexistence [...] should be preserved and deepened" between traditional and new history. ${ }^{88}$

\section{Rational Knowledge about the Past as the Ultimate Goal of Historical Studies}

Given Stankovićs continual interest in theoretical and methodological problems in historical research, at first glance it seems surprising that he almost completely failed to take a stance on the postmodernist objections to the scientific character of historiography, which reached their peak in major global historiographies during the last two decades of the $20^{\text {th }}$ century ${ }^{89}$ Keeping in mind that Stankovic tenaciously insisted on the need to study the past in a systematic fashion and establish rational historical insights, the postmodernist charge on the status of history as a (social) science and its reduction to merely one of the many mutually equivalent discourses about the past, must have been completely unacceptable to him. Stanković succinctly assessed this sweeping relativism, characteristic of postmodernist thinking, and its rejection of all metanarratives (including those about the possibility of acquiring true knowledge) as "pessimism that we cannot accept, especially not today". In that sense and similarly to Richard Evans, Stanković came forward "in defense of history" against those who uncritically denied the possibility of acquiring historical insights. He emphasized, by contrast, the importance of taking a scholarly approach to the study of history, highlighting that it was a matter of vital significance "to the people of that region, who are at the moment lying under a dark cloud of mythomania and centuries-old stereotypes." ${ }^{90}$

Stanković pointed to the existence and widespread presence of historical stereotypes already at the beginning of the 1980s, when he participated in organizing and carrying out a study on the presence of "the Yugoslav and the national in secondary school history textbooks." Among other things, this study showed that "inadequately personalized history" with a pronounced dominance of numerous political figures, had as its consequence "quite a dosed irrational component in constructing images of the past," which led students "onto the path of dehumanization and mythology". Given that the crisis and later collapse of the Yugoslav state provided

88 Stanković, Istorijski stereotipi i naučno znanje, 214-215.

89 Cf. Михаел Антоловић, „Постмодернизам и/или историографија?“, Токови историје 3-4/2008, 177-197.

90 Stanković, Istorijski stereotipi i naučno znanje, 313. 
additional impetus for the spread of different historical stereotypes, the creation of vulgarized historical representations and the brutal exploitation of the past for political ends, Stanković pointed to the "terrifying" fact that the task of interpreting Yugoslav history was left to individuals without adequate knowledge, who were operating in "a vicious circle of stereotypes, or the medieval golden age, western or eastern culture, $19^{\text {th }}$ century government programs, idealization of language or culture, national economic and educational prosperity." ${ }^{\prime 1}$ Bearing in mind the aforementioned social circumstances and the fact that historical knowledge was largely overlooked in public discourse, Stanković persistently advocated a deconstruction of historical stereotypes from the standpoint of scientific rationality. In numerous works, he aimed to demonstrate the unfoundedness of certain stereotypical notions which were circulating in the public domain. These primarily included the stereotypes about the political role of Nikola Pašić, ${ }^{92}$ followed by those about Greater Serbian hegemony in the Kingdom of SCS/Yugoslavia, ${ }^{93}$ as well as the stereotypes about Yugoslavia as the "fatal mistake" of Serbian politics. He dedicated the last book published during his lifetime to refuting this last stereotype. ${ }^{94}$

Đorđe Stanković believed that confronting historical stereotypes with scholarly knowledge was the most important task of historical research and its core social mission. Following Hans-Georg Gadamer, he argued that the task of historical research was "to take at least the first step through its autonomous insights and show [...] that it is possible to create a sphere of moral social and political life based on elementary solidarity among the people living in the entire region of south-eastern Europe, as was the case two and a half millennia ago in the ancient city-state!"95 According to Stanković, historical research could respond to such a task primarily by deconstructing stereotypes through the acquisition of rational, objective insights about the past: "It is with ruthless scholarly criticism that existing stereotypes and false products of national romanticism should be eradicated." He especially underlined that the stereotypes to which he was referring should not be "confused with patriotism." ${ }^{96} \mathrm{He}$

\footnotetext{
$91 \quad$ Ibid., 288.

92 Ibid., 31-46.

93 Ibid., 101-185.

94 Đorđe Stanković, Srbija i stvaranje Jugoslavije, (Beograd: Službeni glasnik, 2009). = Ђорђе Станковић, Србија 1914-1918. Ратни циљеви, (Нови Сад: Прометеј, Београд: РТС, 2014).

95 Stanković, Istorijski stereotipi i naučno znanje, 251.

96 Ibid., 277.
} 
further highlighted that the condition for acquiring objective insights about the past consisted in "democratic relations pervaded with utmost tolerance in dialogue, freedom of academic expression, and a fully implemented right to academic knowledge of history, without the interference of those factors that commit 'spiritual violence' against historical testimonies and historians." ${ }^{\prime 97}$

It is precisely "surveillance over historiography" in its "search for rational knowledge" about the past, which represents the central motif of Stanković's short history of historiography, titled From Mythology to Science. ${ }^{98}$ Following the French historian Marc Ferro, Stanković was of the opinion that the acquisition of new insights about the past had, throughout history, been under the surveillance of the powers that be. Quite consistently, after a chapter on the "victory of the critical method," dedicated to the making of scholarly historiography in the $19^{\text {th }}$ century, Stankovic concluded his overview by pointing to the different ways in which historical research had been ideologically functionalized and instrumentalized in authoritarian political regimes during the first half of the 20th century ("for the benefit of the state, nation, party").

With his, for Serbian historiography, pioneering work on the history of historiography, Stanković did not, however, exhaust his interest in ideological control over rational discoveries about the past. In the period after 2000, he directed his attention to the phenomenon of historiographical revisionism. Present in history since being established as an academic discipline, revisionism became one of the most distinct features of historical studies in former socialist countries, occurring as part of a broader process of rejecting and/or reevaluating the socialist era, and, in that sense, it is a pan-European phenomenon. ${ }^{99}$ Sharing Branko Petranović's opinion that "if it is revision in the name of a new ideologization, then it, too, is targeted by historical research as an unscholarly orientation,"100 Stanković persistently pointed out that the process of revising contemporary Serbian history was not based on scholarly research, judging that

97 Станковић, Изазов нове историје, II, 246-247.

98 Станковић, Димић, Историографија под надзором, I, 27-155.

99 Cf. Gegen Erinnerung. Geschichte als politisches Argument im Transformationsprozess Ost-, Ostmittel- und Südosteuropas, hrsg. von Helmut Altrichter, Elisabeth Müller-Luckner, (München: Oldenbourg, 2006); Past in the Making. Historical Revisionism in Central Europe after 1989, ed. by Michael Kopeček, (Budapest, New York: CEU Press, 2008); Зоран Малбашић, „Историјски ревизионизам: прогрес науке или идеолошко оружје?", Политичка ревија 2/2016, 169-185.

100 Петрановић, Историчар и савремена епоха, 40. 
"both rational and irrational exploitation of the past is increasingly taking the form of irreconcilability, and scholarly knowledge is gaining use-value." Stanković identified the causes of historical revisionism in early $21^{\text {st }}$ century Serbia in the co-occurrence of three factors. The first had to do with the changed social environment in which historical research was operating and spreading its insights, and which had, for a quarter of a century before, been marked by the predominance of the electronic media as the main sources of shaping public consciousness. Stanković recognized the second factor in the distribution of political power, emphasizing that Serbian authorities after the 2000 political revolution had supported the reevaluation of recent history if it was "of use in the technology of ruling" and if it helped to legitimize the new social order, which was based on the uncritical acceptance of neoliberalism as the new political ideology. ${ }^{101} \mathrm{Fi}-$ nally, Stanković identified the provincialism of contemporary Serbian historiography and its weak interest in new paths of development in contemporary historical thought as extremely important factors in the existence of historical revisionism. In a situation where "everyone was running away from 'global scholarship' and satanically confining themselves to parochial mythologies," Stanković emphasized that a distinctive feature of Serbian historiography was, apart from the almost exclusive focus on topics from political history, the historians' low levels of general and professional (theoretical and methodological) knowledge. He considered that one of the consequences of such a situation was the predominance of "positivistic archivitis" as a core concept in Serbian historiography, which was oftentimes reduced to "retelling the contents of documents of different origins - regardless of their authenticity."102 The symbiosis of the aforementioned general social circumstances and the specific peculiarities of Serbian historiography, confronted with social modernization based on, among other things, "a critical and tolerant reexamination of the past," had as its consequence the vulgarization of historical studies and the creation of new (national, religious, ideological) stereotypes, which projected contemporary values into the past and functionalized historical insights in favor of the ruling ideology. ${ }^{103}$

Stanković juxtaposed "impassioned revisionism," which he considered dangerous to the integrity of scholarly historiography, with "critical historical research," which was based on the gradual advancement of

101 Станковић, Неизвесна прошлост Србије, 82-84, 99.

102 Ibid., 107, 115.

103 Ibid., 97. 
historical insights in accordance with the availability of historical sources, as well as on the continual (self-)education of historians in "the domain of theoretical and methodological innovations" and historiographical trends in Europe and the world. ${ }^{104}$ Never questioning the pluralism of historical research in terms of its thematic foci, theoretical and methodological approaches and interpretational aspects, Stanković repeatedly insisted on the need for "every scholarly historian to be thoroughly familiar with the heuristic method, have finely honed criteria for evaluating sources, be familiar with the dominant social values of the time, consider, in places where historical sources allow it, comparative methods and cliometrics, which allow him to present mosaically the clarity of past reality, appreciate multidisciplinarity and the findings of historical research, on the foundations of which he is standing." This he considered to be particularly important, given that "by examining available historical sources gradually and very critically, historical research is attempting to reach the highest level of scholarly knowledge." In view of the empirical groundedness of historical research, Stanković emphasized that "through historical sources, the historian uses scholarly presentation to convey past lives and realities into the present, and, in doing so, creates certain scholarly knowledge and a certain historical consciousness. On the theoretical level, only through empirical research is it possible to create the product that we call history. It does not matter whether that historical realism subjectively stylizes the contents of past realities, in the same way that the artist of the same movement is convinced that he is recreating reality - historical research has no other alternative but to adhere to historical records and the requirements determined by their contents." ${ }^{105}$

At the turn of the century, Đorđe Stanković was one of the few historians of his generation committed to working on the theoretical and methodological aspects of historical research. Drawing on the concept of new history, which left its mark on the main streams of development in world historiography in the 1960s and 1970s, Stanković opted for social history, which employs theoretical and methodological concepts of the social sciences in order to overcome the inherent shortcomings of traditional political history and comes close to the ideal of total history. His final

104 Ibid., 176, 196.

105 Ibid., 20, 221, 226. 
theoretical and methodological response to the revisionist currents within Serbian historiography was critical historical research (modeled on historical social science - Historische Sozialwissenschaft - which was promoted by the Bielefeld School of social history). ${ }^{106}$ With his broadly conceived program of new history, Stanković greatly contributed to the theoretical and methodological development of Serbian historiography, the pluralization of topics it covered, and the establishment of the long and unduly neglected social history and its subdisciplines, such as quantitative and demographic history, the history of everyday (private) life, and gender history. A firm believer in the emancipatory power of scholarly (historical) knowledge, Stanković considered that the deconstruction of stereotypical notions about the past was the most important function of historical research, with which it contributed to man's liberation and to the creation of a more humane and more just society. That is precisely why, in a time of social and political crisis fuelled by the dissolution of socialist Yugoslavia and followed by a spread of historical stereotypes and the strengthening of false historiography in public discourse, ${ }^{107}$ Stanković tenaciously highlighted that securing rational insights about the past was the first and foremost goal of historical research. It is in this same sense that one should understand the fact that Stanković advocated the theoretical and methodological development of scholarly historiography, so that it could, with its extent and comprehensiveness, analyticity and nuanced interpretations, respond to its primary social role. However, looking at the main trends in contemporary Serbian historiography, ${ }^{108}$ it seems that his new history program has been only partially adopted. This is not only due to the fact that certain theoretical concepts that Stanković once had great hopes for were received quite unenthusiastically by Serbian historians (this was the case with, e.g. psychohistory, which, it should be mentioned, has almost completely fallen off the radar of world historiography), but even more due to the continual disregard for theoretical and methodological issues in Serbian historiography and its focus on "amassing" knowledge, mainly from the domain of political history. ${ }^{109}$

106 Јирген Кока, О историјској науци. Огледи, превео с немачког Бранимир Живојиновић, (Београд: СКЗ, 1994).

107 Cf. Andrej Mitrović, Klio pred iskušenjima i raspravljanja sa Klio, (Beograd: Čigoja, 2001); Радивој Радић, Срби пре Адама и после њега. Историја једне злупотребе: слово против „новоромантичара“, (Београд: Стубови културе, 2003).

108 Cf. Predrag Marković, Nataša Milićević, „Serbian Historiography in the Time of Transition: a Struggle for Legitimacy", Istorija 20. veka 1/2007, 145-166.

109 Јовановић, Радић, Криза историје, 55-132. 
With his new history program, Đorđe Stanković has played one of the key roles in the process of modernizing Serbian historiography from the mid-1980s until the early 21 st century. This fact alone makes him one of the most significant figures in Serbian historiography of that period. In addition to greatly advancing the (national) field of history with his theoretical works, Đorđe Stanković's historiographical writings have provided a permanent incentive for both the critical evaluation of Serbian and Yugoslav historiographical heritage and the necessary strengthening of self-reflection within historical research. In that sense, the academic oeuvre of Đorđe Stanković is not just a valuable legacy, but it also provides reliable guidance to future generations of historians in the organized "dialogue of the past and the present."

\section{Literature}

- Антоловић, Михаел. „Постмодернизам и/или историографија?“ Токови историје 3-4/2008, 177-197.

- Антоловић, Михаел. „О занату историчара: теоријско-методолошка схватања Чедомира Попова“. Споменица академику Чедомиру Попову. Нови Сад: Матица српска, 2017, 9-34.

- Антоловић, Михаел. „In memoriam - Ђорђе Станковић (1944-2017)“ Споменица Историјског архива Срем 16/2017, 265-267.

- Бјелајац, Миле. „Проф. др Ђорђе Станковић (1944-2017)“ Токови истоpuje $3 / 2017,169-172$.

- Бонџи, Драгомир. „Настанак историографије о Београдском универзитету 1945-1980“. Историја 20. века 1/2005, 153-168.

- Bondžić, Dragomir. „Razvoj istoriografije o Beogradskom univerzitetu 19802004“. Istorija 20. veka 1/2006, 125-140.

- Burke, Peter. New Perspectives on Historical Writing. University Park, PA: The Pennsylvania State University Press, 2001.

- Дашић, Миомир. Спорења у историографији. О врлинама и манама „Учитељище живота". Подгорица: ИТП Унирекс, Бијело Поље: ИГП ПЕГАЗ, 2014.

- Димић, Љубодраг. „Марјановић, Јован“. Енциклопедија српске историографије, прир. Сима Ћирковић и Раде Михаљчић. Београд: Knowledge, 1997, 482-483.

- Димић, Љубодраг. „Петрановић, Бранко“. Енциклопедија српске историографије прир. Сима Ћирковић и Раде Михаљчић. Београд: Knowledge, 1997, 570-572.

- Еванс, Ричард. Уодбрану историје, превод са енглеског и поговор Ристо Тубић. Београд: СКЗ, 2007. 
- Đurović, Smiljana. „Nadzor pod nadzorom. Metodološka razmatranja o tome kuda idu kretanja u procesima saznanja“. Tokovi istorije 3-4/1997, 245-255.

- Furet, François. „De l'histoire-récit à l'histoire-problème“. Diogène: revue internationale des sciences humaines 89/1975, 116-131.

- Фире, Франсоа. Радионица историје, превела с француског Јелена Новаковић. Сремски Карловци, Нови Сад: ИКЗС, 1994.

- $\quad$ Gegen Erinnerung. Geschichte als politisches Argument im Transformationsprozess Ost-, Ostmittel- und Südosteuropas, Hrsg. von Altrichter, Helmut und Elisabeth Müller-Luckner. München: Oldenbourg, 2006.

- Grafenauer, Bogo. Struktura in tehnika zgodovinske vede: uvod v študij zgodovine. Ljubljana: Univerzitetna založba, 1960.

- Grafenauer, Bogo. „Problemi metodologije istorijskih nauka u svetlu nekoliko novih radova o metodologiji istorije“.Jugoslovenski istorijski časopis 1/1965, 41-68.

- Gross, Mirjana. „Historija: ideologija i (ili) znanost“. Istoriografija, marksizam i obrazovanje. Beograd: Izdavački centar Komunist, 1986, 163-179.

- $\quad$ Historija i suvremenost. Idejne kontroverze. Zagreb: Centar CK SKH za idejnoteorijski rad „Vladimir Bakarić“, Delo, Globus, 1984.

- Hobsbawm, Eric. „From Social History to the History of Society“. Daedalus 1/1971, 20-45.

- Hobsbaum, Erik. $O$ istoriji. O teoriji, praksi i razvoju istorije i njenoj relevantnosti za savremeni svet, preveo sa engleskog Mašan Bogdanovski. Beograd: Otkrovenje, 2003.

- $\quad$ Hudelist, Darko. Moj beogradski dnevnik. Susreti i razgovori s Dobricom Ćosićem 2006-2011. Zagreb: Profil, 2012.

- $\quad$ Iggers, Georg G. Ein anderer historischer Blick. Beispiele ostdeutscher Sozialgeschichte. Frankfurt am Main: Fischer-Taschenbuch-Verlag, 1991.

- $\quad$ Igers, Georg G. Istorijska nauka u 20. veku. Kritički pregled u međunarodnom kontekstu. Beograd: Arhipelag, 2014.

- Janković, Branimir. Mijenjanje sebe same. Preobrazbe hrvatske historiografije kasnog socijalizma. Zagreb: Srednja Europa, 2016.

- Јовановић, Мирослав, Радивој Радић. Криза историје. Српска историографија и друштвени изазови краја 20. и почетка 21. века. Београд: УДИ, 2009.

- Кока, Јирген. О историјској науци. Огледи, превео с немачког Бранимир Живојиновић. Београд: СКЗ, 1994.

- $\quad$ Past in the Making. Historical Revisionism in Central Europe after 1989, ed. by Michael Kopeček. Budapest, New York: CEU Press, 2008.

- $\quad$ Koren, Snježana. Politika povijesti u Jugoslaviji (1945-1960). Komunistička partija Jugoslavije, nastava povijesti, historiografija. Zagreb: Srednja Europa, 2012.

- Малбашић, Зоран. „Историјски ревизионизам: прогрес науке или идеолошко оружје?“ Политичка ревија 2/2016, 169-185. 
- $\quad$ Marjanović, Jovan. „Uvodna reč“. Jugoslovenski istorijski časopis 1/1962, 3-4.

- Marković, Predrag, Nataša Milićević. „Serbian Historiography in the Time of Transition: a Struggle for Legitimacy“. Istorija 20. veka 1/2007, 145-166.

- $\quad$ Metodologija savremene istorije (Saopštenja sa Okruglog stola održanog 17. i 18. decembra 1985. godine u Beogradu), ur. Petar Kačavenda. Beograd: ISI, 1987.

- $\quad$ Mitrović, Andrej i drugi. Studenti Beogradskog univerziteta (1838-1941): hronologija političkog života. Beograd: Univerzitetski odbor za proslavu 50 godina SKJ i SKOJ, 1971.

- Митровић, Андреј. „Седам теза о месту и улози историјске науке у историјској свести“. Марксистичка мисао 4/1983, 3-19.

- Митровић, Андреј. „Савременост и историјска свест“. Марксистичка мисао 2/1985, 3-19.

- $\quad$ Mitrović, Andrej. Raspravljanja sa Klio. Oistoriji, istorijskojsvestiiistoriografiji. Sarajevo: Svjetlost, 1991.

- Mitrović, Andrej. Vreme destruktivnih. Intervjui, priredio Dragan Štavljanin. Čačak: Čačanski glas, 1998.

- Mitrović, Andrej. Klio pred iskušenjima i raspravljanja sa Klio. Beograd: Čigoja, 2001.

- Mitrović, Momčilo, Đorđe Stanković. Zapisi i izveštaji Univerzitetskog komiteta KPS 1945-1948. Beograd: Centar za marksizam Univerziteta, 1985.

- $\quad$ Mitrović, Momčilo, Đorđe Stanković. Zapisnici i izveštaji IKKPS 1948-1952. Beograd: Centar za marksizam Univerziteta, 1987.

- Митровић, Момчило, Ђорђе Станковић. Записници Акционог одбора ССУ Београдског универзитета 1939-1941. Београд: Центар за марксизам Универзитета, 1988.

- Najbar-Agičić, Magdalena. U skladu sa marksizmom ili činjenicama? Hrvatska historiografija 1945-1960. Zagreb: Ibis grafika, 2013.

- Никола Пашић у Народној скупштини, књ. IV, приредио Ђорђе Станковић. Београд: Службени лист СРЈ, 1998.

- Николић, Коста. Прошлост без историје. Полемике у југословенској историографији 1961-1991. Београд: Институт за савремену историју, 2003.

- Пашић, Никола. Слога Србо-Хрвата, приредио Ђорђе Станковић. Београд: Време књиге, 1995.

- Perović, Latinka. „Dva značajna istoriografska dela: povodom drugog izdanja knjige Branka Petranovića, Istoričar i savremena epoha i dvotomnog dela Đorđa Stankovića i Ljubodraga Dimića, Istoriografija pod nadzorom“. Istorija 20. veka 1/1998, 163-168.

- $\quad$ Petranović, Branko. Istoriografija i revolucija. Beograd: Prosveta, 1984.

- Petranović, Branko. „Venceslav Glišić, Užička republika“. Jugoslovenski istorijski časopis 1-2/1987, 187-199. 
- Petranović, Branko. „Đorđe Stanković, Nikola Pašić i jugoslovensko pitanje“. Jugoslovenski istorijski časopis 3/1987, 147-166.

- Петрановић, Бранко. Југословенско искуство српске националне интеграције. Београд: Службени лист СРЈ, 1993.

- Петрановић, Бранко. Историчар и савремена епоха. Београд: Новинско-издавачка установа „Војска“, 1994.

- Петрановић, Бранко. Историографске контроверзе. Београд: Службени лист СРЈ, 1998.

- Петрановић, Бранко. „Дезинтеграција историјске свести о револуцији“. Марксистичка мисао 4/1983, 59-82.

- Попов, Чедомир. „Револуција и историографија. Расправе“. Марксистичка мисао 6/1986, 189-192.

- Problemi jugoslovenske istorijske nauke“. Jugoslovenski istorijski časopis 3/1964, 57-94.

- „Problemi jugoslovenske istorijske nauke (nastavak)“.Jugoslovenski istorijski časopis 4/1964, 93-107.

- Р. „Станковић Ђ. Ђорђе“. Енциклопедија српске историографије, прир. Сима Ћирковић, Раде Михаљчић, 647-648. Београд: Knowledge, 1997.

- Радић, Радивој. Срби пре Адама и после њега. Историја једне злупотребе: слово против „новоромантичара“. Београд: Стубови културе, 2003.

- Радојевић, Мира, Љубодраг Димић. „In memoriam - Ђорђе Станковић (1944-2017)“, Политика, 17. август 2017.

- Роксандић, Драго. „Глобална историја и историјска свест“. Марксистичка мисао 4/1983, 45-58.

- Роксандић, Драго. „Савременост и историјска свест“. Марксистичка миcao 2/1985, 78-86.

- Roksandić, Drago. „Istorijske sudbine. Sjećanje na prof. dr Đorđa Stankovića (Sloboština, 21.1.1944. - Beograd, 9. 8. 2017.)“ Prosvjeta 142/2018, 56-57.

- Станковић, Ђорђе. „Adam Schaff, Histoire et Vérité. Essai sur l'Objectivité de la Connaissance Historique, Paris 1971; Paul Ricoeur, Histoire et Vérité, Paris s. a.; Geoffrey Barraclough, An Introduction to Contemporary History, London 1970; Sidney Pollard, The Idea of Progress. History and Society, London 1971“. Историјски гласник 1-2/1974, 173-178.

- Станковић, Ђорђе. „Maurice Bouvier-Ajam, Essai de méthodologie historique, Paris 1970; Joseph Hours, Valeur de l'histoire, Paris 1971; Paul Veyne, Comment on écrit l'histoire, Paris 1971; Antoine Pelletier, Jean-Jacques Goblot, Matérialisme historique et histoire des civilizations, Paris 1973; André Beaufre, La nature de l'histoire, Paris 1974; Léon-E. Halkin, Éléments de critique historique, Liège 1974“. Историјски гласник 1-2/1976, 183-187.

- Станковић, Ђорђе. „Нове могућности проучавања револуционарног субјекта“. Марксистичка мисао 6/1981, 186-206.

- Станковић, Ђорђе. „Социјална историја и личност“. Марксистичка миcao 4/1983, 33-44. 
- Станковић, Ђорђе. „Београдски универзитет - политичке и историографске контроверзе“. Марксистичка мисао 5/1983, 165-180.

- $\quad$ Stanković, Đorđe. Nikola Pašić, saveznici i stvaranje Jugoslavije. Beograd: Nolit, 1984.

- Станковић, Ђорђе. Никола Пашић и југословенско питање, I-II. Београд: БИГЗ, 1985.

- $\quad$ Stanković, Đorđe. Iskušenja jugoslovenske istoriografije. Beograd: Rad, 1988.

- Станковић, Ђорђе. Изазов нове историје, I-II. Београд: Новинско-издавачка установа „Војска“, 1992-1994.

- Станковић, Ђорђе. Никола Пашић и Хрвати (1918-1923). Београд: БИГЗ, 1995.

- Станковић, Ђорђе. Никола Пашић, савезници и стварање Југославије, друго проширено издање. Зајечар: Задужбина „Никола Пашић“, 1995.

- Станковић, Ђорђе, Љубодраг Димић. Историографија под надзором, III. Београд: Службени лист СРJ, 1996.

- Станковић, Ђорђе. Студенти и универзитет 1914-1954: огледи из друштвене историје. Београд: Центар за савремену историју југоисточне Европе, 2000.

- $\quad$ Stanković, Đorđe. Istorijski stereotipi i naučno znanje. Beograd: Plato, 2004.

- Станковић, Ђорђе. Никола Пашић. Прилози за биографију. Београд: Плато, 2006.

- Stanković, Đorđe. Srbija i stvaranje Jugoslavije. Beograd: Službeni glasnik, 2009.

- Станковић, Ђорђе. Србија 1914-1918. Ратни циљеви. Нови Сад: Прометеј, Београд: РТС, 2014.

- Станковић, Ђорђе. Неизвесна прошлост Србије. Одабрани научни есеји. Нови Сад: Прометеј, 2014.

- Сто говора Николе Пашића: вештина говорништва државника, I-II, приредио Ђорђе Станковић. Београд: Рад, 2007.

- Терзић, Милан. „In memoriam - Ђорђе Станковић 1944-2017“. Војноисторијски гласник 2/2017, 337-339. 


\section{Summary}

At the turn of the century, Đorđe Stanković was one of the few historians of his generation who were committed to working on the theoretical and methodological aspects of historical research. Drawing on the concept of new history, which left its mark on the main streams of development in world historiography in the 1960s and 1970s, Stanković opted for social history, which employs theoretical and methodological concepts of the social sciences in order to overcome the inherent shortcomings of traditional political history and comes close to the ideal of total history. With his broadly conceived program of new history, Stanković contributed significantly to the theoretical and methodological development of Serbian historiography, the pluralization of topics it covered, and the establishment of the long and unduly neglected social history and its subdisciplines, such as quantitative and demographic history, the history of everyday (private) life, and gender history. A firm believer in the emancipatory power of scholarly (historical) knowledge, Stanković considered that the deconstruction of stereotypical notions about the past was the most important function of historical research, with which it contributed to man's liberation and to the creation of a more humane and more just society. That is precisely why, in a time of social and political crisis fuelled by the dissolution of socialist Yugoslavia and followed by a spread of historical stereotypes and the strengthening of false historiography in public discourse, Stanković persistently highlighted that securing rational insights about the past was the first and foremost goal of historical research. It is in this same sense that one should understand the fact that Stanković advocated the theoretical and methodological development of scholarly historiography, so that it could, with its extent and comprehensiveness, analyticity and nuanced interpretations, respond to its primary social role. With his new history program, Đorđe Stanković has played one of the key roles in the process of modernizing Serbian historiography from the mid-1980s until the early 21st century. This fact alone makes him one of the most significant figures in Serbian historiography of that period. In addition to greatly advancing the (national) field of history with his theoretical works, Đorđe Stanković's historiographical writings have provided a permanent incentive for both the critical evaluation of Serbian and Yugoslav historiographical heritage and the necessary strengthening of self-reflection within historical research. In that sense, the academic oeuvre of Đorđe Stanković is not just a valuable legacy, but also provides reliable guidance to future generations of historians in the organized "dialogue of the past and the present." 


\title{
Резиме
}

Михаел Антоловић

Биљана Шимуновић-Бешлин

\section{Историја као Vallis Aurea. Ђорђе Станковић и модернизација српске историографије}

\begin{abstract}
Апстракт: У раду су представљене теоријско-методолошке концепције Ђорђа Станковића у контексту развоја и модернизације српске и југословенске историографије крајем 20. и на почетку 21. века. У фокусу истраживања били су: Станковићево разумевање епистемолошких основа историјске науке и њених друштвених функција, његов програм „нове историје“ и доследна борба за деконструкцију историјских стереотипа и афирмацију рационалних, научних знања.
\end{abstract}

Кључне речи: Ђорђе Станковић, теорија историје, методологија историјских наука, југословенска историографија, српска историографија, „нова историја“, социјална историја

Током последњих деценија 20. и прве деценије 21. века Ђорђе Станковић је био један од ретких историчара у својој генерацији који су се предано бавили теоријом и методологијом историјске науке. Полазећи од концепта „нове историје“, који је током 60-их и 70-их обележио главне правце развоја светске историографије, Станковић се определио за социјалну историју која, служећи се теоријско-методолошким концептима друштвених наука, превазилази инхерентне недостатке традиционалне политичке историје и омогућава приближавање идеалу - „тоталној историји“. Својим широко заснованим програмом „нове историје“ битно је допринео теоријско-методолошком развоју српске историографије, њеној тематској плурализацији, конституисању дуго неоправдано запостављене социјалне историје и њених субдисциплина попут квантитативне и демографске, историје свакодневног (приватног) живота, те родне историје. Чврсто верујући у еманципаторску моћ научног (историјског) сазнања, сматрао је да деконструкција стереотипних представа о прошлости представља најважнију функцију историјске науке којом она доприноси ослобађању човека и стварању хуманијег и праведнијег 
друштва. Управо стога, током раздобља друштвене и политичке кризе, подстакнут распадом социјалистичке Југославије, праћеним ширењем историјских стереотипа и снажењем параисториографије у јавном дискурсу, Станковић је упорно указивао на то да је обезбеђивање рационалних знања о прошлости први и најважнији циљ историјске науке. У поменутом контексту ваља разумети и његово заговарање теоријско-методолошког развоја научне историографије, како би она, обимом и обухватношћу сазнања, аналитичношћу и изнијансираним интерпретацијама, могла да одговори својој превасходној друштвеној улози. Ђорђе Станковић је програмом „нове историје“ одиграо једну од кључних улога у процесу модернизације српске историографије од средине осамдесетих година 20. и на почетку 21. столећа. Ова чињеница га, већ сама по себи, чини једном од најзначајнијих личности српске историографије у том раздобљу. Осим што је својим теоријским радовима умногоме унапредио (националну) историјску културу, својим историографским делом је дао трајан подстицај како за критичко вредновање српске и југословенске историографске баштине тако и за неопходно снажење саморефлексивности историјске науке. Стога научни опус Ђорђа Станковића не само да представља драгоцено наслеђе у српској историографији већ пружа и сигуран путоказ будућим генерацијама историчара у организованом „дијалогу прошлости и садашњости“. 